\title{
Pengaruh Aktivitas Tambang Galian C Terhadap Perubahan Lingkungan Fisik di Kecamatan Parangloe Kabupaten Gowa
}

\section{The Influence of C-Excavation Mining Activities on Physical Environment Changes in Parangloe District, Gowa Regency}

\author{
M. Riza Pratama ${ }^{1}$, Fadhil Surur ${ }^{2 *}$ \\ Teknik Perencanaan Wilayah dan Kota, Fakultas Sains dan Teknologi, Universitas Islam Negeri \\ Alauddin Makassar, Indonesia \\ *corresponding author, email: fadhil.surur@uin-alauddin.ac.id
}

Manuscript received: 28-11-2020. Accepted: 22-03-2021

\begin{abstract}
ABSTRAK
Kegiatan penambangan galian yang ada di Kabupaten Gowa selain menyumbang PAD juga telah mengakibatkan berbagai dampak kerusakan lingkungan berupa penurunan permukaan tanah, pengikisan (erosi), pengendapan (sedimentasi), kebisingan, debu dan terganggunya muka air tanah. Kondisi tersebut tidak hanya menyebabkan menurunnya kualitas lingkungan tetapi juga memberikan dampak yang sangat serius bagi kesehatan dan jiwa manusia. Penelitian ini bertujuan untuk mengetahui seberapa besar pengaruh aktivitas tambang galian $\mathrm{C}$ terhadap perubahan kondisi lingkungan fisik dan menentukan strategi pengelolaan tambang galian $\mathrm{C}$ Kecamatan Parangloe Kabupaten Gowa. Metode pengumpulan data dilakukan dengan teknik observasi lapangan, wawancara, survey instansi, dokumentasi dan metode telaah pustaka. Analisis yang digunakan dalam penelitian ini yaitu analisis regresi berganda dan analisis SWOT. Berdasarkan hasil analisis diperoleh bahwa aktivitas pertambangan berpengaruh terhadap prasarana, kualitas lingkungan dan kelembagaan. Sedangkan aktivitas pertambangan tidak berpengaruh terhadap sarana. Adapun strategi pengelolan tambang galian berdasarkan hasil analisis adalah strategi yang menggunakan kekuatan dan memanfaatkan peluang yaitu pengelolaan tambang galian $\mathrm{C}$ dengan memanfaatkan teknologi dan sumberdaya lokal dalam meningkatkan perekonomian daerah.
\end{abstract}

Kata kunci: pertambangan; kualitas lingkungan; strategi

\begin{abstract}
In addition to contributing PAD, the excavation mining activities in Gowa have also resulted in various impacts of environmental damage in the form of land subsidence, erosion, deposition (sedimentation), noise, dust and disturbed groundwater levels. This condition not only causes a decrease in the quality of the environment but also has a very serious impact on human health and psyche. This study aims to determine how much influence the c excavation mining activity has on changes in physical environmental conditions and to determine the mining management strategy of the c quarry in Parangloe District, Gowa Regency. The method of data collection was carried out by
\end{abstract}


using field observation techniques, interviews, agency surveys, documentation and literature review methods. The analysis used in this study is multiple regression analysis and SWOT analysis. Based on the results of the analysis, it is found that mining activities affect infrastructure, environmental quality and institutions. Meanwhile, mining activities do not affect the facilities. The quarry management strategy based on the results of the analysis is a strategy that uses strength and takes advantage of opportunities, namely the management of mining $\mathrm{C}$ by utilizing local technology and resources in improving the regional economy.

Key words: mining; environmental quality; strategy

\section{PENDAHULUAN}

Dalam pembukaan Undang-Undang Nomor 32 Tahun 2009 tentang perlindungan dan pengelolaan lingkungan hidup menyatakan bahwa kualitas lingkungan hidup semakin menurun telah mengancam kelangsungan perikehidupan manusia dan makhluk hidup lainnya sehingga perlu di lakukan perlindungan dan pengelolaan lingkungan hidup yang sungguhsungguh dan konsisten oleh semua pemangku kepentingan. Kualitas lingkungan hidup adalah kondisi dan keadaan unsur-unsur atau komponen-komponen lingkungan hidup, baik komponen biota maupun komponen abiotik yang sesuai dengan spesifikasi yang diinginkan dan atau sesuai dengan standar mutu lingkungan (Rizal, 2017).

Potensi di Kabupaten Gowa memiliki kekayaan berupa tambang mineral bukan logam sebagai salah satu sumber PAD terbesar. Luas areal tambang mineral bukan logam seluas 271 ha berupa pasir, batuan dan tanah timbunan yang terdapat di Kecamatan Bontomarannu, Kecamatan Pallangga, Kecamatan Pattalassang, Kecamatan Parangloe, dan Kecamatan Manuju. Karim et.al (2012) dalam Marini, et.al (2014). Salah satu usaha penambangan yang banyak ditemui di Kabupaten Gowa adalah penambangan bahan galian golongan $\mathrm{C}$, bahan galian yang mudah dijumpai dan keberadaannya sangat dibutuhkan masyarakat dalam hal membangun fasilitas maupun infrastruktur.

Kegiatan penambangan galian yang ada di Kabupaten Gowa telah mengakibatkan berbagai dampak kerusakan lingkungan berupa penurunan permukaan tanah, pengikisan (erosi), pengendapan (sedimentasi), kebisingan, debu dan terganggunya muka air tanah, hal ini ditandai dengan banyaknya jalan-jalan di Kabupaten Gowa yang mengalami patah dan tidak adanya potensi air tanah dangkal disekitar kegiatan pertambangan. Kondisi tersebut tidak hanya menyebabkan menurunnya kualitas lingkungan tetapi juga memberikan dampak yang sangat serius bagi kesehatan dan jiwa manusia.

Kecamatan Parangloe merupakan salah satu kecamatan di Kabupaten Gowa yang lintasi oleh Sungai Jeneberang yang alirannya membawa material-material tambang yang berasal dari Gunung Bawakaraeng. Melihat besarnya potensi bahan galian yang terdapat di Kecamatan Parangloe menyebabkan banyaknya kegiatan usaha pertambangan baik perorangan ataupun yang terlibat dengan badan usaha. Kecamatan Parangloe merupakan salah satu kecamatan di Kabupaten Gowa yang lintasi oleh Sungai Jeneberang yang alirannya membawa material-material tambang yang berasal dari Gunung Bawakaraeng. Melihat besarnya potensi bahan galian yang terdapat di Kecamatan Parangloe menyebabkan 
banyaknya kegiatan usaha pertambangan baik perorangan ataupun yang terlibat dengan badan usaha.

Pemanfaatan bahan galian di DAS Jeneberang merupakan masalah serius karena meningkatnya luas lahan kritis sebagai dampak dari pengelolaan lahan yang tidak sesuai dengan kemampuannya dan perubahan pola penggunaan lahan bervegetasi. DAS Jeneberang dengan luas areal 38.552 ha memiliki permasalahan yaitu erosi dan tanah longsor sebagai indikator kegagalan dalam mengelola sumber daya alam yang memiliki manfaat publik (Nurdin, et.al 2014).

\section{BAHAN DAN METODE}

Penelitian ini akan dilaksanakan pada Bulan September 2019 sampai dengan Bulan Februari 2020. Lokasi penelitian dilakukan di DAS Jeneberang Kecamatan Parangloe Kabupaten Gowa, meliputi 5 desa/kelurahan dari 7 desa/kelurahan yang dilalui oleh Sungai Jeneberang. Data yang digunakan terbagi atas data primer dan sekunder. Data primer adalah data yang diperoleh melalui pengamatan langsung pada objek penelitian dilapangan seperti kondisi eksisiting, kondisi jaringan jalan, kondisi persampahan, kualitas udara dan kualitas air, sedangkan data sekunder diperoleh dari instansi-instansi terkait.

\section{Populasi dan Sampel}

Populasi adalah keseluruhan aspek tertentu dari ciri, fenomena, atau konsep yang menjadi pusat perhatian. Populasi dalam penelitian ini adalah masyarakat yang bermukim di lokasi penelitan meliputi 5 desa/kelurahan dengan jumlah penduduk secara keselurahan sebanyak 13.916 jiwa berdasarkan data Badan Pusat Statistik Kabupaten Gowa Tahun 2019. Sampel adalah bagian dari jumlah dan karakteristik yang dimiliki oleh populasi tersebut. Bila populasi besar, dan peneliti tidak mungkin mempelajari semua yang ada pada populasi, misalnya karena keterbatasan dana, tenaga dan waktu, maka peneliti dapat menggunakan sampel yang diambil dari populasi tersebut (Sugiyono, 2017). Secara matematis besarnya sampel dari suatu populasi dapat menggunakan rumus slovin, yaitu:

Keterangan:

$$
\boldsymbol{n}=\frac{\mathbf{N}}{\mathbf{1}+\mathbf{N e}^{2}}
$$

n : Jumlah Sampel

$\mathrm{N} \quad$ : Jumlah Populasi

e : Koefisien kelonggaran ketidaktelitian karena kesalahan pengambilan sampel yang masih dapat ditolerir atau diinginkan $(10 \%)$

Berdasarkan rumus diatas, maka pengambilan sampel pada studi kasus di Kecamatan Pallangga dengan populasi sebanyak 14.078 jiwa adalah sebagai berikut: 


$$
\begin{gathered}
n=\frac{\mathrm{N}}{1+\mathrm{Ne}^{2}} \\
n=\frac{13.916}{1+13.916(10 \%)^{2}} \\
n=99,9 \text { atau } 100 \text { Responden }
\end{gathered}
$$

Jadi, sampel yang diperlukan dalam penelitian ini sebanyak 100 responden dari keseluruhan populasi. Untuk lebih jelasnya dapat dilihat pada Tabel 1 berikut:

Tabel 1. Jumlah Penduduk Daerah Penelitian

\begin{tabular}{lcc}
\hline $\begin{array}{c}\text { Nama } \\
\text { Desa/Kelurahan }\end{array}$ & $\begin{array}{c}\text { Jumlah Penduduk } \\
\text { (Jiwa) }\end{array}$ & $\begin{array}{c}\text { Distribusi } \\
\text { Responden }\end{array}$ \\
\hline Lonjobokko & 2.852 & 20 \\
Bontokassi & 1.270 & 10 \\
Borisallo & 3.157 & 20 \\
Lanna & 3.474 & 25 \\
Bontoparang & 3.163 & 25 \\
\multicolumn{1}{c}{ Total } & $\mathbf{1 3 . 9 1 6}$ & $\mathbf{1 0 0}$ \\
\hline
\end{tabular}

Variabel Penelitian

Tabel 2. Variabel Penelitian

\begin{tabular}{cl}
\hline Variabel Penelitian & \multicolumn{1}{c}{ Indikator } \\
\hline Prasarana & $\bullet$ Persampahan \\
& $\bullet$ Jaringan Jalan \\
& $\bullet$ Air Bersih \\
& $\bullet$ Drainase \\
\hline Sarana & - Sarana Pendidikan \\
& $\bullet$ Sarana Kesehatan \\
& $\bullet$ Sarana Perdagangan \\
& $\bullet$ Kualitas Udara \\
\hline Kualitas Lingkungan & $\bullet$ Debit Air \\
\hline Kelembagaan & $\bullet$ Kelompok Masyarakat \\
\hline
\end{tabular}

Analisis data yang digunakan terbagi dua, yaitu analisis regresi berganda dan analisis swot. Adapun tahapan dalam analisis, dapat dijelaskan sebagai berikut:

\section{Analisis Regresi Berganda}

Analisis regresi berganda digunakan oleh peneliti, jika bermaksud untuk meramalkan bagaimana keadaan (naik-turunnya) variabel dependen (kriterium), bila dua atau lebih variabel independen sebagai predictor dimanipulasi (dinaikturunkan nilainya). Jadi analisis regresi berganda akan dilakukan jika jumlah variabel independennya minimal 2 Hadi, (2016) dalam Susilawati, et,al (2017). Berikut merupakan rumus regresi berganda: 


$$
Y=a+b 1 x 1+b 2 x 2+b 3 x 3+b 4 x 4+\ldots
$$

Keterangan:

$\begin{array}{ll}\mathrm{Y} & \text { : Kegiatan Pertambangan } \\ \mathrm{a} & : \text { Konstanta } \\ \mathrm{b} & \text { : Koefisien, b1,b2,b3,b3,b4: Koefisien Regresi } \\ \mathrm{x} 1 & : \text { Prasarana } \\ \mathrm{x} 2 & : \text { Sarana } \\ \mathrm{x} 3 & : \text { Kualitas Lingkungan } \\ \text { x4 } & \text { : Kelembagaan }\end{array}$

\section{Analisis SWOT}

Matriks SWOT adalah matriks yang menginteraksikan faktor strategis internal dan eksternal. Matriks ini dapat menggambarkan secara jelas bagaimana peluang dan ancaman (eksternal) yang dihadapi dapat disesuaikan dengan kekuatan dan kelemahan (internal) yang dimiliki. Indikator yang menjadi bahan dilakukan pengujian untuk mendapatkan hasil yang akan diterapkan dengan analisis SWOT yang meliputi peniaian terhadap faktor kekuatan (Strength) dan kelemahan (Weakness). Sementara, analisis eksternal mencakup faktor peluang (Opportunity) dan tantangan (Threaths). Analisis SWOT ini merupakan alat formulasi pengambilan keputusan serta untuk menentukan strategi yang ditempuh berdasarkan kepada logika untuk memaksimalkan kekuatan dan peluang, namun secara bersamaan dapat meminimalkan kelemahan dan ancaman (Ikshan, 2011).

\section{HASIL DAN PEMBAHASAN}

Secara geografis lokasi penelitian berada di sepanjang sempadan sungai jenebereng yang berada di wilayah administrasi Kecamatan Parangloe, yang secara administrasi mencakup 5 desa/kelurahan yakni Kelurahan Lanna, Kelurahan Bontoparang, Desa Borisallo, Desa Bontokassi dan Desa Bontoparang. Luas wilayah penelitian di sempadan sungai jeneberang Kecamatan Parangloe yakni $16,36 \mathrm{~km}^{2}$ yang diberi radius $500 \mathrm{~m}$ dari palung sungai. Wilayah tersebut merupakan daerah dengan ketinggian rata-rata 0-500 mdpl dan kemiringan lereng yakni $0-25 \%$.

Kecamatan Parangloe merupakan salah katu wilayah di Kabupaten Gowa yang memiliki potensi dibidang sentra produksi mineral berupa pasir, batuan, dan tanah timbunan. Material tersebut berasal dari gunung bawakaraeng yang mengalami fenomena geologi yang mengakibatkan munculnya material-material tersebut yang kemudian terbawa oleh aliran Sungai Jeneberang. Dengan kondisi seperti ini Kecamatan Parangloe merupakan kecamatan penghasil bahan tambang pasir dan batu kali terbesar di Kabupaten Gowa.

Walupun begitu banyak masalah yang ditimbulkan oleh keberadaan aktivitas tambang galian tersebut, salah satunya adalah masalah terhadap lingkungan fisik berupa kerusakan jalan, debu dan kebisingan yang disebabkan oleh aktivitas truk pengangkut hasil galian. Beberapa upaya telah dilakukan oleh pemerintah dan pihak kepolisian setempat untuk meminimalisir dampak yang berpengaruh terhadap masyarakat sekitar salah satunya adalah dengan melakukan sweeping dan memberikan peringatan para pelaku usaha galian dan supir 
truk. Namun tidak dapat dipungkiri bahwa sektor ini merupakan salah satu sektor yang memberikan lapangan kerja bagi masyarakat. Berdasarkan data Dinas Energi dan Sumber Daya mineral saat ini terdapat 31 industri batuan dan mineral yang memiliki izin baik berupa perusahaan maupun industri perorangan yang masing-masing memiliki luasan area galian dengan luas total 433,09 Ha.

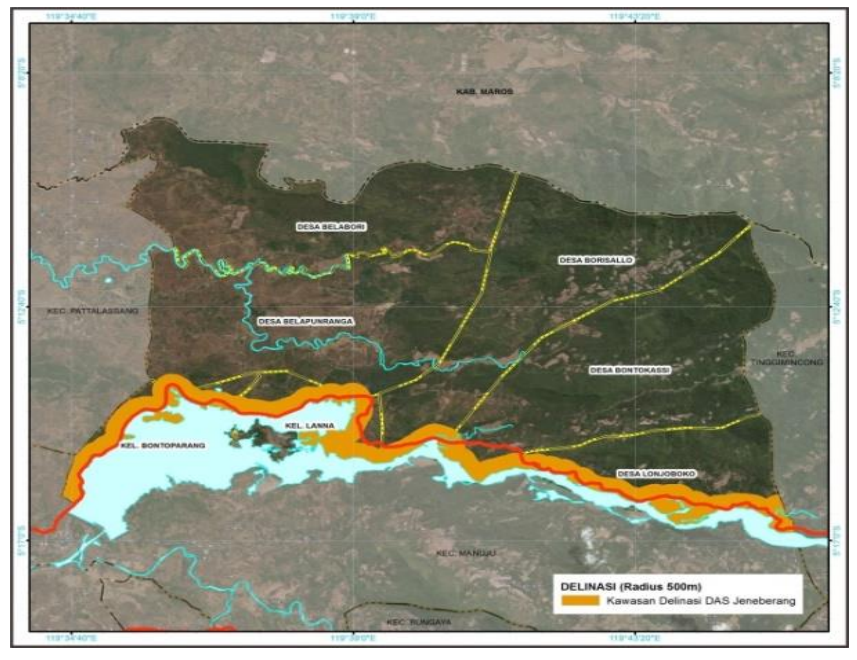

Gambar 1. Peta Kawasan Penelitian

\section{Metode Regresi Berganda terhadap Pengaruh Aktivitas Tambang Galian C}

\section{Konsep dasar analisis regresi berganda}

a. Analisis regeresi berganda bertujuan untuk mengetahui ada atau tidaknya pengaruh dua atau lebih variabel bebas $(\mathrm{X})$ terhadap variabel terikat (Y).

b. Uji t bertujuan untuk mengetahui ada atau tidaknya pengaruh parsial (sendiri) yang diberikan variabel bebas $(\mathrm{X})$ terhadap variabel terikat $(\mathrm{Y})$.

c. Koefisien determinasi bertujuan untuk mengetahui berapa persen pengaruh yang diberikan variabel $(\mathrm{X})$ secara simultan terhadap variabel $(\mathrm{Y})$.

\section{Uji koefisien determinasi $(R 2)$}

Koefisien determinasi pada intinya mengukur seberapa jauh kemampuan model menerapkan variabel dari variabel dependen. Koefisien determinasi di dapatkan dengan mengkuadratkan $\mathrm{R}^{2}$. Dari hasil analisis diperoleh nilai R2 sebesar 0,341 sehingga dapat ditarik kesimpulan bahwa variabel (X) secara simultan yaitu prasarana, sarana, kualitas lingkungan, dan kelembagaan mempengaruhi lingkungan fisik Kecamatan Parangloe sebesar $34,1 \%$. Untuk lebih jelasnya uji koefisien determinasi dapat dilihat pada Tabel 3 berikut: 
Tabel 3. Hasil Uji Koefisien Determinasi (R2)

\begin{tabular}{ccccc}
\hline Model & $\mathrm{R}$ & R Square & $\begin{array}{c}\text { Adjusted } \mathrm{R} \\
\text { Square }\end{array}$ & $\begin{array}{c}\text { Std. Error of the } \\
\text { Estimate }\end{array}$ \\
\hline 1 & $0,584^{\mathrm{a}}$ & 0,341 & 0,313 & 0,345 \\
\hline
\end{tabular}

\section{Uji $t$}

a. Dasar pengambilan keputusan

1) Jika nilai sig $<0,05$ atau $\mathrm{t}$ hitung $>\mathrm{t}$ tabel maka terdapat pengaruh variabel $(\mathrm{X})$ terhadap variabel (Y).

2) Jika nilai sig $>0,05$ atau $t$ hitung $<\mathrm{t}$ tabel maka tidak terdapat pengaruh variabel $(\mathrm{X})$ terhadap variabel $(\mathrm{Y})$.

$$
\text { t tabel }=(\alpha / 2 ; n-k-1)=t(0,025 ; 95)=1,985
$$

\section{b. Hasil hipotesis dengan Uji $t$}

Analisis pengaruh individual atau parsial (Uji t) bertujuan untuk mengetahui variabel independen secara parsial mempunyai pengaruh yang signifikan terhadap variabel dependen. Pengambilan keputusan dalam uji t didasarkan pada tingkat signifikansi sebesar $5 \%$ atau 0,05 . Untuk lebih jelasnya hasil hipotesis (uji t) dan rekapitulasi dapat dilihat pada Tabel 4 berikut:

Tabel 4. Hasil Hipotesis Dengan Uji t

\begin{tabular}{crrrrr}
\hline \multirow{2}{*}{ Model } & \multicolumn{2}{c}{$\begin{array}{l}\text { Unstandardized } \\
\text { Coefficients }\end{array}$} & $\begin{array}{c}\text { Standardized } \\
\text { Coefficients }\end{array}$ & \multirow{2}{*}{$\mathrm{t}$} & \multirow{2}{*}{ Sig. } \\
\cline { 2 - 5 } & \multicolumn{1}{c}{$\mathrm{B}$} & Std. Error & Beta & & \\
\hline (Constant) & $-0,649$ & 0,284 & & $-2,284$ & 0,025 \\
\hline Total_X1 & 0,043 & 0,014 & 0,278 & 3,081 & 0,003 \\
\hline Total_X2 & $6,084 \mathrm{E}-005$ & 0,008 & 0,001 & 0,007 & 0,994 \\
\hline Total_X3 & 0,073 & 0,014 & 0,462 & 5,137 & 0,000 \\
\hline Total_X4 & 0,086 & 0,021 & 0,342 & 4,091 & 0,000 \\
\hline
\end{tabular}

Tabel 5. Hasil Rekapitulasi Pengaruh Variabel Parsial (X) terhadap Variabel Terikat (Y)

\begin{tabular}{ll}
\hline \multicolumn{1}{c}{ Variabel $(\mathbf{X})$} & \multicolumn{1}{c}{ Keterangan } \\
\hline Prasarana & Berpengaruh \\
\hline Sarana & Tidak Berpengaruh \\
\hline Kualitas Lingkungan & Berpengaruh \\
\hline Kelembagaan & Berpengaruh
\end{tabular}

Dari hasil analisis diketahui bahwa variabel yang mempengaruhi aktivitas tambang galian c terhadap perubahan lingkungan fisik di Kecamatan Parangloe Kabupaten Gowa adalah sebagai berikut: 
1) Pengujian hipotesis prasarana (X1)

Diketahui nilai sig untuk pengaruh (X1) terhadap (Y) adalah sebesar 0,003 $<0,05$ dan nilai t hitung 3,081 > t tabel 1,985 sehingga dapat disimpulkan bahwa (X1) diterima yang berarti terdapat pengaruh terhadap (Y).

2) Pengujian hipotesis sarana (X2)

Diketahui nilai sig untuk pengaruh (X2) terhadap (Y) adalah sebesar 0,994>0,05 dan nilai t hitung $0,007<\mathrm{t}$ tabel 1,985 sehingga dapat disimpulkan bahwa (X2) ditolak yang berarti tidak terdapat pengaruh terhadap $(\mathrm{Y})$.

3) Pengujian hipotesis kualitas lingkungan (X3)

Diketahui nilai sig untuk pengaruh (X3) terhadap (Y) adalah sebesar $0,000<0,05$ dan nilai t hitung 5,137 > t tabel 1,985 sehingga dapat disimpulkan bahwa (X3) diterima yang berarti terdapat pengaruh terhadap $(\mathrm{Y})$.

4) Pengujian Hipotesis Kelembagaan (X4)

Diketahui nilai sig untuk pengaruh (X4) terhadap (Y) adalah sebesar 0,000 $<0,05$ dan nilai t hitung 4,091 > t tabel 1,985 sehingga dapat disimpulkan bahwa (X4) diterima yang berarti terdapat pengaruh terhadap $(\mathrm{Y})$.

\section{Arahan Pengelolaan Tambang Galian C}

\section{Analisis Faktor Internal}

Analisis mengenai faktor internal dimulai dengan melakukan pembobotan dan pemeringkatan terhadap faktor-faktor kekuatan dan kelemahan dalam arahan pengelolaan tambang galian c di Kecamatan Parangloe Kabupaten Gowa. Pembobotan diisi oleh informan dengan jumlah 2 orang, yaitu dari pihak pemerintah Kecamatan parangloe dan staf Kelurahan Lanna. Untuk lebih jelasya pembobotan responden terhadap masing-masing factor internal dapat dilihat pada Tabel 6 berikut:

Tabel 6. Penilaian Bobot dan Rating Faktor Internal

\begin{tabular}{lccr}
\hline \multicolumn{1}{c}{ Faktor Internal } & Bobot & Rating & Skor \\
\hline Kekuatan & & & \\
\hline Sumber daya mineral dan batuan yang besar & 0,202 & 3,5 & 0,707 \\
\hline Ketersediaan teknologi pertambangan yang memadai & 0,134 & 3,2 & 0,429 \\
\hline Aksesibilitas menuju lokasi tambang mendukung & 0,165 & 3,4 & 0,561 \\
\hline \multicolumn{1}{c}{ Jumlah } & & & $\mathbf{1 , 6 9 6}$ \\
\hline Kelemahan & 0,165 & 3 & 0,495 \\
\hline Ativitas tambang galian tidak memperhatikan lingkungan fisik & 0,165 & 2,8 & 0,462 \\
\hline Penurunan kualitas prasarana & 0,169 & 3 & 0,507 \\
\hline Tidak adanya kegiatan rehabilitasi lahan pascatambang & $\mathbf{1}$ & & $\mathbf{1 , 4 6 4}$ \\
\hline \multicolumn{1}{c}{ Jumlah } &
\end{tabular}

Selanjutnya adalah mengalikan jumlah bobot dengan jumlah rating untuk menentukan skor dari masing-masing indikator kekuatan dan kelemahan, dimana faktor kekuatan bernilai positif dan faktor kelemahan bernilai negatif. Berdasarkan skor faktor kekuatan dan skor 
faktor kelemahan menunjukkan bahwa posisi faktor internal pada arahan pengeloaan tambang galian c di Kecamatan Parangloe Kabupaten Gowa secara umum berada pada posisi kuat yaitu dengan nilai 0,232 (1.696-1,464).

\section{Analisis Faktor Eksternal}

Pembobotan eksternal dilakukan terhadap beberapa parameter eksternal berupa peluang dan ancaman. Sama halnya dengan factor internal, pembobotan factor eksternal dimulai dengan melakukan pembobotan dan pemeringkatan terhadap faktor-faktor peluang dan ancaman dalam arahan pengelolaan tambang galian c di Kecamatan Parangloe Kabupaten Gowa. Pembobotan diisi oleh informan dengan jumlah 2 orang, yaitu dari pihak pemerintah Kecamatan parangloe dan staf Kelurahan Lanna. Untuk lebih jelasya pembobotan responden terhadap masing-masing factor internal dapat dilihat pada Tabel 7 berikut:

Tabel 7. Penilaian Bobot dan Rating Faktor Eksternal

\begin{tabular}{lccc}
\hline \multicolumn{1}{c}{ Faktor Eksternal } & Bobot & Rating & Skor \\
\hline Peluang & & & \\
\hline Mampu menyerap tenaga kerja & 0,129 & 3,5 & 0,451 \\
\hline Kebutuhan pasar akan bahan material terus meningkat & 0,194 & 3,4 & 0,659 \\
\hline Meningkatkan PAD Jumlah & 0,194 & 3,3 & 0,640 \\
\hline \multicolumn{1}{c}{ Ancaman } & & & $\mathbf{1 , 7 5 1}$ \\
\hline Berpotensi menimbulkan bencana alam & 0,160 & 3 & 0,480 \\
\hline Adanya aktivitas tambang illegal & 0,194 & 2,9 & 0,562 \\
\hline Penurunan kualitas udara & 0,129 & 2,9 & 0,374 \\
\hline \multicolumn{1}{c}{ Jumlah } & $\mathbf{1}$ & $\mathbf{1 , 4 1 6}$ \\
\hline
\end{tabular}

Selanjutnya adalah mengalikan jumlah bobot dengan jumlah rating untuk menentukan skor dari masing-masing indikator peluang dan ancaman, dimana faktor peluang bernilai positif dan faktor ancaman bernilai negatif. Berdasarkan skor faktor peluang dan skor faktor ancaman menunjukkan bahwa posisi faktor eksternal pada arahan pengeloaan tambang galian c di Kecamatan Parangloe Kabupaten Gowa secara umum berada pada posisi kuat yaitu dengan nilai 0,335 (1.751-1,416).

Berdasarkan hasil analisis terhadap faktor internal dan eksternal maka diperoleh total skor faktor internal 0,232 dan total skor faktor eksternal 0,335. Diketahui bahwa nilai strategi pengembangannya berada pada kuadran I (Growth), maka dapat di tentukan beberapa konsep pengembangan yang dapat mendukung dalam arahan pengelolaan tambang galian $\mathrm{C}$ di Kecamatan Parangloe Kabupaten Gowa. Strategi yang tepat berdasarkan hasil analisis adalah strategi yang menggunakan kekuatan dan memanfaatkan peluang (strengths-opportunities) berupa strategi "pengelolaan tambang galian $\mathrm{C}$ dengan memanfaatkan teknologi dan sumberdaya lokal dalam meningkatkan perekonomian daerah". 


\section{KESIMPULAN}

Dari hasil analisis diperoleh bahwa aktivitas tambang galian C di Kecamatan Parangloe Kabupaten Gowa berpengaruh terhadap prasarana, kualitas lingkungan dan kelembagaan sedangkan aktivitas pertambangan tidak berpengaruh terhadap sarana.

Strategi Pengelolaan Aktivitas Tambang Galian C di Kecamatan Parangloe Kabupaten Gowa sebagai berikut: a. Mengadakan pelatihan kerja berbasis pemanfaatan teknologi pertambangan seperti pelatihan pengoperasian alat berat, mekanisme penggalian dan mekanisme pengoperasian moda trasnportasi pertambangan guna untuk meningkatkan serta mengembangkan kompetensi kerja yang dapat memberi manfaat bagi perusahaan dan tenaga kerja, b. Mengadakan sosialisasi terkait aktivitas pertambangan yang melibatkan tenaga kerja dan masyarakat yang bermukim di sekitar industri tambang galian guna untuk meningkatkan pemahaman publik terhadap sektor pertambangan baik berupa aspek positif maupun negative, c. Menambah jumlah tenaga kerja dengan mengutamakan masyarakat lokal guna untuk mengurangi tingkat pengangguran, d.Mengadakan kemitraan terhadap sektor swasta, perusahaan kontraktor dan lembaga swadaya masyarakat dalam pengembangan industri tambang galian guna untuk meraih keuntungan bersama dengan perinsip saling membutuhkan dan saling membesarkan, e. Mengadakan fasilitas pendukung kegiatan pertambangan seperti koperasi dan fasilitas kesehatan untuk tenaga kerja pertambangan guna untuk menjamin kegiatan peroduksi perusahaan tambang galian berjalan dengan gangguan yang minimum.

\section{DAFTAR PUSTAKA}

Aslam, et.al., 2015. Peranan Pemerintah Dalam Penertiban Penambangan Ilegal Nikel di Kabupaten Kolaka Utara. Jurnal Program Studi Ilmu Pemerintahan Fakultas Ilmu Ssosial dan Ilmu Politik. Vol V. Universitas Muhmmadiyah Makassar.

Badan Pusat Statistik Kabupaten Gowa. 2019. Kabupaten Gowa Dalam Angka 2019. Badan Pusat Statistik. Gowa.

Badan Pusat Statistik Kabupaten Gowa. 2019. Kecamatan Parangloe Dalam Angka 2019. Badan Pusat Statistik. Gowa.

Buli, Willyam., 2018. Strategi Pengendalian Kerusakan Lingkungan Melalui Pembenahan

Kelembagaan Pertambangan Batubara Tanpa Izin Studi Kasus Di Kabupaten Muara

Enim Provinsi Sumatera Selatan. Bandar Lampung. Program Pascasarjana. Universitas Lampung.

Dyahwanti, Inarni Nur. 2007. Kajian Dampak Lingkungan Kegiatan Penambangan Pasir Pada Daerah Sabuk Hijau Gunung Sumbing Di Kabupaten Temanggung. Program Studi Ilmu Lingkungan. Universitas Diponegoro.

Ikhsan. et.al., 2011. Analisis Swot Untuk Merumuskan Strategi Pengembangan Komoditas

Karet di Kabupaten Pulang Pisau. Jurnal Agribisnis Perdesaan Vol. 01. Fakultas Pertanian Universitas Lambung Mangkurat. Banjarmasin.

Khaerunnisa, Isti., 2011. Penilaian Kualitas Lingkungan Permukiman Kawasan Pecinan Kota Semarang. Perencanaan Wilayah Dan Kota. Universitas Diponegoro. 
Manalu, et.al., 2014. Kesiapan Pemerintah Kabupaten Muara Enim Dalam Rangka Menanggulangi Pencemaran Batubara. Jurnal Ekologi Kesehatan Vol. 13. Pusat Teknologi Intervensi Kesehatan Masyarakat.

Mardani, Anggi Alvionita., 2016. Analisis Eksploitasi Sumber Daya Alam Guna Meningkatkan Kesejahteraan Masyarakat Dalam Perspektif Ekonomi Islam. Jurusan Ekonomi Islam. UIN Raden Intan Lampung.

Marini, et.al., 2014. Penerimaan Informasi Dampak Penambangan Pasir Bagi Kerusakan Lingkungan Hidup Dikalangan Penambang Pasir Ilegal Di Das Jeneberang Kabupaten Gowa. Jurnal Ilmu Komunikasi Vol. 3. Fakultas Ilmu Sosial Dan Ilmu Politik Universitas Hasanuddin.

Nurdin, et.al., 2000. Sektoral Agenda Pertambangan untuk Pengembangan Kualitas Hidup Secara Berkelanjutan. Universitas Diponegoro. Jakarta.

Nurdin, et.al., 2014. Studi Pemulihan Fungsi Das Berdasarkan Tingkat Kekritisan Lahan Dan Potensi Kelongsoran Di Sub Das Jeneberang Hulu. Jurnal Teknik Pengairan Vol. 5. Universitas Brawijaya. Malang.

Pananrangi, Idham., 2013. Perubahan Fungsi Lahan. Alauddin University Press. Makassar.

Patiung, et.al., 2011. Pengaruh Umur Reklamasi Lahan Bekas Tambang Batubara Terhadap Fungsi Hidrologis. Jurnal Hidrolitan Vol. 2.

Rasyid, Yusra Hidayat., 2017. Implementasi Kebijakan Penataan Ruang Wilayah Sempadan Sungai Jeneberang Di Kecamatan Somba Opu Kabupaten Gowa. Program Studi Ilmu Pemerintahan. Universitas Hasanuddin.

Rizani, Mohammad Debby., 2019. Pengelolaan Sanitasi Permukiman Wilayah Perkotaan Dengan Pendekatan Terknokratik Dan Partisipatif (Teknoparti). Media Sahabat Cendekia.

Rizkiana, Rahmi Dyah Hajeng., 2012. Pengelolaan Usaha Penambangan Bahan Galian Golongan C, Di Desa Darmakradenan Kecamatan Ajibarang Kabupaten Banyumas. Kementrian Pendidikan Dan Kebudayaan. Universitas Jenderal Soedirman.

Salim, Aditya Rohmatullah., 2018. Kerugian Ekonomi Pada Infrastruktur Dan Usaha Pertanian Akibat Aktivitas Pertambangan Di Kecamatan Cigudeg, Kabupaten Bogor. Departemen Ekonomi Sumberdaya Dan Lingkungan. Institut Pertanian Bogor.

Setiawan, Fahri., 2018. Analisis Kecamatan Prioritas Untuk Pembangunan Sarana Dan Prasarana di Kawasan Pasca Tambang Timah Kabupaten Bangka Selatan. Journal of Regional and Rural Development Planning. Sekolah Pascasarjana. Institut Pertanian Bogor.

Sugiyono., 2014. Metode Penelitian Kuantitatif Kualitatif Dan R\&D. Alfabeta. Bandung. Yusuf, Muhammad., 2017. Penegakan Hukum Terhadap Tindak Pidana Pertambangan Gol.C Tanpa Izin. Departemen Hukum Pidana. Universitas Hasanuddin. 